\title{
CARDIOVASCULAR COLLAPSE ASSOCIATED WITH NITROUS OXIDE ANAESTHETIC: A CASE REPORT
}

\author{
John R. Dayidson and Herbert M. Chinyanga
}

\begin{abstract}
This is a case report of a one year old infant weighing 6.7 kilograms with a preoperative diagnosis of partial anomalous pulmonary venous drainage whose anaesthetic was complicated by cardiovascular collapse following addition of nitrous oxide to oxygen administered to the patient using a T-piece breathing circuit. The cardiovascular pathopharmacology of all the drugs administered to the patient before the event as well as that of nitrous oxide is discussed in detail. The drugs discussed are atropine $0.1 \mathrm{mg}(0.01$ $\left.\mathrm{mg} \cdot \mathrm{kg}^{-1}\right)$, glycopyrrolate $0.07 \mathrm{mg}\left(0.01 \mathrm{mg} \cdot \mathrm{kg}^{-1}\right)$, morphine $0.9 \mathrm{mg}\left(0.14 \mathrm{mg} \cdot \mathrm{kg}^{-1}\right)$ methylprednisone sodium succinate $165 \mathrm{mg}\left(23.5 \mathrm{mg} \cdot \mathrm{kg}^{-1}\right)$ sodium thiopentone $40 \mathrm{mg}$ $\left(5.7 \mathrm{mg} \cdot \mathrm{kg}^{-1}\right)$, metocurine $3.4 \mathrm{mg}\left(0.4 \mathrm{mg} \cdot \mathrm{kg}^{-1}\right)$.
\end{abstract}

Key WoRdS: ANAESThetics, Gases, nitrous oxide; Complications, congenital heart disease, cardiovascular collapse.

Nitrous oxIDE, in appropriate concentrations, is regarded as the most benign agent in modern anaesthetic practice. Though its effects on systemic and pulmonary vascular impedance and blood flow are usually of little clinical significance, the following report describes a case in which nitrous oxide apparently caused cardiovascular collapse in a patient with congestive heart failure (CHF).

\section{CASE REPORT}

A one-year-old infant with partial anomalous pulmonary venous drainage (PAPVD), which had been diagnosed by cardiac catheterization eight months earlier, was admitted for surgical correction after medical management with digoxin (0.4 $\mathrm{mg}$ twice daily) and hydrochlorothiazide ( $8 \mathrm{mg}$ twice daily) failed to control congestive heart failure.

Cardiac catheterization on this admission showed that the right pulmonary veins emptied into the right atrium, confirming the original diagnosis (Figure 1). It also disclosed diffuse

John R. Davidson, M.D., R4 1980, Department of Anaesthesia, University of Westem Ontario, London, Ontario, Canada; Herbert M. Chinyanga, M.D., F.R.C.P.(C), Staff Anaesthetist, The Hospital for Sick Children, Department of Anaesthesia, University of Toronto, Toronto, Ontario, Canada.

Address for Correspondence and Reprints: Dr. H.M. Chinyanga, Department of Anaesthesia, The Hospital for Sick Children, 555 University Avenue, Toronto, Ont., Canada, M5G 1 X8.

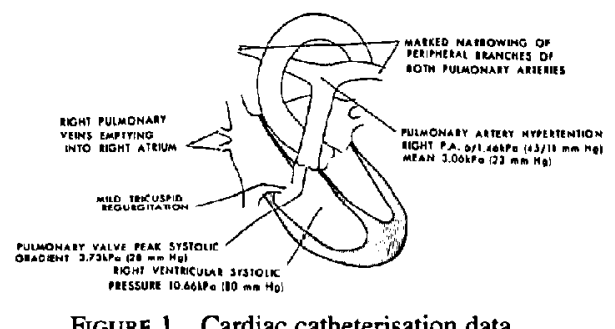

FIGURE 1 Cardiac catheterisation data.

hypoplasia of the peripheral branches of both pulmonary arteries with a right ventricular systolic pressure of $10.66 \mathrm{kPa}(80 \mathrm{~mm} \mathrm{Hg})$ (normal: 2.26-4.26, mean $3.33 \mathrm{kPa}(17-32$, mean 25 $\mathrm{mm} \mathrm{Hg})$ ). In addition, there was a mild tricuspid regurgitation. At catheterization arterial blood gases on room air were: $\left[\mathrm{H}^{+}\right] \mathrm{a} 40.74 \mathrm{nmol} / \mathrm{l}(\mathrm{pH}$ 7.39) $\mathrm{PCO}_{2} 4.00 \mathrm{kPa}(30 \mathrm{~mm} \mathrm{Hg}) \mathrm{HCO}_{3}{ }^{-} 17.5$ $\mathrm{mmol} / \mathrm{l}$, Base Excess $-6 \mathrm{mmol} / 1$ and $\mathrm{PO}_{2} 8.93$ $\mathrm{kPa}(67 \mathrm{~mm} \mathrm{Hg})$.

Operation was delayed for 18 days because gastroenteritis developed and was followed by right middle lobe pneumonia. The latter was treated with amoxicillin and chest physiotherapy for eight days.

At preoperative assessment the patient weighed $6.7 \mathrm{~kg}$. He was afebrile and grayish looking. His chest was clear on both physical and radiographic examination. He had a Grade III/VI systolic ejection murmur which was best heard at the left sternal border. Haemoglobin was $11 \mathrm{gm} / 100 \mathrm{ml}$ and haematocrit was 37.1 per

Can. Anaesth. Soc. J., vol. 29, no. 5, September 1982 
cent. Venous blood gases and serum electrolytes were normal.

He was premedicated with morphine $1 \mathrm{mg}$ $\left(0.14 \mathrm{mg} \cdot \mathrm{kg}^{-1}\right.$ body weight) intramuscularly 45 minutes before induction of anaesthesia. On arrival in the operating room, electrocardiograph, blood pressure cuff and a precordial stethoscope were applied. His blood pressure was $12 \mathrm{kPa}(90 \mathrm{~mm} \mathrm{Hg})$ systolic by palpation and he was in sinus rhythm with a rate of 135 beats per minute.

After four minutes of pre-oxygenation, the patient was given methylprednisone sodium succinate $165 \mathrm{mg}$ (IVMP) $\left(23.5 \mathrm{mg} \cdot \mathrm{kg}^{-1}\right.$ body weight) intravenously in anticipation of the planned period of circulatory arrest under profound hypothermia during operation. This was followed by glycopyrrolate $0.07 \mathrm{mg}(0.01$ $\mathrm{mg} \cdot \mathrm{kg}^{-1}$ body weight) a vagolytic agent. Anaesthesia was induced with morphine $2 \mathrm{mg}$ ( $0.3 \mathrm{mg} \cdot \mathrm{kg}^{-1}$ body weight) and thiopentone sodium $40 \mathrm{mg}\left(5.7 \mathrm{mg} \cdot \mathrm{kg}^{-1}\right.$ body weight). Metocurine $3.5 \mathrm{mg}\left(0.5 \mathrm{mg} \cdot \mathrm{kg}^{-1}\right.$ body weight $)$ ) was given intravenously to provide muscle relaxation. After two or three minutes of intermittent positive pressure ventilation (IPPV) with 100 per cent oxygen delivered by face mask, a $4.5 \mathrm{~mm}$ internal diameter uncuffed clear tracheal tube was inserted. Ventilation was continued manually and then mechanically with oxygen at a flow rate of six litres per minute. At this point the blood pressure was $11.33 \mathrm{kPa}(85$ $\mathrm{mm} \mathrm{Hg}$ ) measured with the aid of a Doppler device placed distal to the blood pressure cuff. The electrocardiogram showed normal sinus rhythm and a heart rate of 132 beats per minute.

After about seven minutes (during which an oesophageal stethoscope, a thermometer probe, a bite block and the tracheal tube were secured with adhesive tape), the oxygen flow was reduced to three litres per minute and an equal amount of nitrous oxide was introduced. An in-line oxygen analyzer confirmed the $\mathrm{FIo}_{2}$ of 0.5 . Within two minutes the patient's blood pressure dropped to $9.33 \mathrm{kPa}(70 \mathrm{~mm} \mathrm{Hg})$ and then to $8 \mathrm{kPa}(60 \mathrm{~mm} \mathrm{Hg})$. The $\mathrm{Flo}_{2}$ was increased to 0.7 but the blood pressure continued to fall to $6 \mathrm{kPa}\left(45 \mathrm{~mm} \mathrm{Hg}\right.$ ) at which point the $\mathrm{Fl}_{\mathrm{O}_{2}}$ was increased to 1.0 and manual IPPV was resumed. Despite this, the blood pressure did not rise and the heart rate fell below 80 beats per minute. Cardiopulmonary resuscitation was then initiated.

Resuscitation was promptly achieved with atropine $0.1 \mathrm{mg}$, sodium bicarbonate $6 \mathrm{mmol}$, isoproterenol $10 \mu \mathrm{g}$ and lactated Ringer's solution $15 \mathrm{ml}$. The blood pressure rose to $13.3 \mathrm{kPa}$ $(100 \mathrm{~mm} \mathrm{Hg})$ and the heart rate to 140 beats per minute and normal sinus rhythm was re-established.

After careful consideration of the patient's prognosis it was decided to proceed with the anaesthetic and surgical repair as originally planned. The balance of the anaesthetic, which included a 100-minute pre-bypass and a 105-minute post-bypass period was uneventful. Anaesthesia and analgesia were maintained with diazepam and morphine. Nitrous oxide was not re-introduced.

\section{Discussion}

This patient had just recovered from two serious illnesses, gastroenteritis and right middle lobe pneumonia. The former, through its ability to cause acute fluid and electrolyte shifts, could have altered his ability to compensate for any adverse changes in cardiac output. Before this illness, the patient was already on digitalis and diuretic therapy. The pneumonia, though resolved at the time of the operation, could have affected the ventilation/perfusion ratio as well as the reactivity of the pulmonary vasculature and airway to mechanical, chemical, and hypoxic changes.

To understand the most likely cause of the cardiovascular collapse in this patient, we examined the cardiovascular pharmacology of the drugs administered before the crucial seven minutes preceding administration of nitrous oxide.

The patient was premedicated with morphine. In a patient on diuretic therapy who has a contracted blood volume secondary to recent gastroenteritis morphine may increase vascular capacity by vasodilation, thereby decreasing cardiac output somewhat. ${ }^{1}$ However, this effect is usually associated with doses of morphine of 1 to $2 \mathrm{mg} \cdot \mathrm{kg}^{-1}$ body weight administered intravenously, ${ }^{2}$ whereas, our patient received only $0.14 \mathrm{mg} \cdot \mathrm{kg}^{-1}$ body weight intramuscularly. Such an effect was not reflected in our patient's blood pressure which was $12 \mathrm{kPa}$ (90 $\mathrm{mm} \mathrm{Hg}$ ) systolic at induction of anaesthesia. Furthermore, morphine has little effect on myocardial function. ${ }^{2}$

The atropine, which was given as a premedicant with the morphine, produced no unusual reaction. The heart was in sinus rhythm with a rate of 135 beats/minute. The small dose 
of atropine given to our patient would have no remarkable effect on circulation. Although atropine may protect the heart against vagal stimuli, it is known to cause bradycardia by a direct effect on the medullary cardiac centre. ${ }^{3}$ Consequently, it may be contraindicated (especially for intravenous use) in conditions of left or right outflow obstructive lesions since it might cause a marked fall in coronary blood flow and cardiac output. ${ }^{4}$ Our patient had mild tricuspid regurgitation and a high peak systolic pressure gradient across the pulmonary valve (Figure 1).

The high dose of IVMP given as a bolus before the induction of anaesthesia could not account for our patient's cardiovascular collapse. In normal subjects $30 \mathrm{mg} \cdot \mathrm{kg}^{-1}$ body weight of this drug as a single intravenous bolus over five to 10 minutes usually produces no significant electrocardiogram or blood changes. 5,6 There may be a slight increase in heart rate. In patients with acute myocardial infarction and those in various types of shock, IVMP (50 and $30 \mathrm{mg} \cdot \mathrm{kg}^{-1}$ body weight respectively) increases cardiac index, reduces peripheral resistance and increases venous capacity. ${ }^{7.8}$ Stubbs and Morrell reported serious cardiovascular complications, including three deaths in four renal transplant recipients, during or soon after intravenous administration of large doses (7-28 $\mathrm{mg} \cdot \mathrm{kg}^{-1}$ body weight) of IVMP as a bolus over 20 seconds to 20 minutes. ${ }^{9}$ All four patients demonstrated serious supra, junctional and ventricular electrocardiogram changes which were associated with severe hypotension and electrocardiogram changes compatible with acute myocardial infarction which cleared over a relatively short period of time were recorded in the patient who recovered.

Two main mechanisms were put forward for this reaction: (a) that the diuretic therapy produced a significantly reduced blood volume and potentiated the vasodilator effect of the steroid, with marked reduction in venous return to the heart resulting in circulatory collapse, or (b) that corticosteroid, acutely administered in the presence of furosemide, which in itself may affect calcium metabolism, interfered with the critical role of calcium in mediating excitation contraction coupling in the myocardium. The benzothiadiazide diuretics do not seem to have any comparable effect on either calcium or cardiac function.

In our patient, the IVMP and all drugs administered at induction were injected through a 25GA $1.3 \mathrm{~cm}: 30.5 \mathrm{~cm}$ Deseret E-Z set - 25 infusion set, with a dead space of $0.4 \mathrm{ml}$. This dead space of the tubing was cleared with $1 \mathrm{ml}$ of $5 \%$ DW 0.2 saline after each drug was administered. No cardiovascular changes were observed following administration of IVMP. However, if an increase in venous capacity had occurred, it would not have been noted since a central venous pressure line had not yet been inserted.

The intravenous administration of glycopyrrolate, which produces a vagal blockade superior to that achieved with atropine (as evidenced by its ability to prevent the acute cardiac reflex) ${ }^{10}$ without causing excessive increases in the heart rate, " had no unusual effect in our patient.

Following the administration of glycopyrrolate, morphine $2 \mathrm{mg}\left(0.3 \mathrm{mg} \cdot \mathrm{kg}^{-1}\right.$ body weight $)$ was given, followed by thiopentone sodium 40 $\mathrm{mg}$ ( $5.7 \mathrm{mg} \cdot \mathrm{kg}^{-1}$ body weight). The changes which morphine can produce have already been discussed. The dose of thiopentone sodium was higher than is usually given $\left(5.7 \mathrm{mg} \cdot \mathrm{kg}^{-1}\right.$ in contrast to the usual $2-5 \mathrm{mg} \cdot \mathrm{kg}^{-1}$ body weight), especially considering this patient's disease state. This dose might have accounted for the events that followed if the time sequence of events had been different. Thiopentone sodium causes hypotension by vasodilation and direct myocardial depression. ${ }^{12-14}$ However, when this complication occurs it is almost immediate, particularly in a patient who is hypovolaemic, whatever the cause. Probably the slow administration of this drug to our patient, who essentially had a left to right (pulmonary vein to right atrium) shunt, prevented adverse effects due to somewhat increased circulation time and dilution by recirculation in the pulmonary circuit.

Metocurine, which was also used, has been favourably regarded for its ability to maintain cardiovascular stability. ${ }^{15}$ Unlike curare, it causes minimal ganglionic blockade or histamine release, ${ }^{16}$ two features which could precipitate hypotension and, unlike pancuronium bromide, it does not appear to cause tachycardia. ${ }^{15}$ Metocurine in high doses (above $0.4 \mathrm{mg} \cdot \mathrm{kg}^{-1}$ body weight may produce some of the adverse reactions caused by curare.

The adverse reaction common to methylprednisolone, morphine, thiopentone sodium and a high dose of metocurine is increased capacity of the vascular bed which can lead to diminished venous return and hypotension. In view of his recent illness and diuretic therapy, our patient 
was indeed a risk. However, nothing catastrophic occurred for seven minutes following administration of all drugs; this amount of time was more than sufficient for any adverse reaction to have occurred and to have manifested itself. Nevertheless, our patient's blood pressure had fallen only slightly (from $12 \mathrm{kPa}(90 \mathrm{~mm} \mathrm{Hg}$ ) before induction to $11.33 \mathrm{kPa}(85 \mathrm{~mm} \mathrm{Hg})$ systolic after induction of anaesthesia and his heart remained in sinus rhythm, with a rate of 132 beats per minute.

When nitrous oxide was introduced into the fresh gas flow, the heart rate and blood pressure fell quickly and steadily and cardiovascular collapse occurred, necessitating cardiopulmonary resuscitation. Nitrous oxide can produce a decrease in both cardiac output ${ }^{17-21}$ and systemic blood pressure. ${ }^{17.18}$ Lappas, et $a l^{18}$ demonstrated a marked rise in pulmonary vascular resistance $\left(318-656\right.$ dynes-sec/ $\left./ \mathrm{cm}^{5}\right)$ together with a fall in mean arterial pressure, cardiac index, stroke index and left ventricular stroke work index when 50 per cent nitrous oxide was added to a narcotic relaxant anaesthetic in patients undergoing coronary artery bypass surgery. This effect was reversed with a phentolamine infusion, substantiating the hypothesis that it is mediated by alpha adrenergic innervation of the pulmonary vasculature. The patients of Lappas $e t$ al received high doses (2 $\mathrm{mg} \cdot \mathrm{kg}^{-1}$ body weight) of morphine.

Our patient had significant impedance to right ventricular output, with obstruction at the pulmonary valve and main branch pulmonary artery levels. Probably his pulmonary arteriolar vascular resistance was normal, reflecting the lower distal pulmonary artery pressures. It appears that in this critically ill patient whose myocardium was close to failure, the administration of nitrous oxide following morphine and sodium thiopentone precipitated acute cardiovascular failure. Nitrous oxide should be avoided or used with extreme caution in critically ill cardiac patients.

\section{ACKNOWLEDGEMENTS}

Our thanks are extended to Dr. Robert Freedom, Division of Cardiology, The Hospital for Sick Children, Toronto, for his interpretation of the cardiac catheterization data, and to Dr. D.J. Steward, Department of Anaesthesia, The Hospital for Sick Children, Toronto, for his suggestions.

\section{REFERENCES}

1. NGaI, S.H. Current concepts in anesthesiology: effects of anesthetics on various organs. N. Engl. J. Med. 302: 564 (1980)

2. MERIN, R.G. Effect of anesthetic drugs on myocardial performance in man Annu. Rev. Med. 28: 75 (1977).

3. INNES, I.R. \& NiCKERSON, M. Atropine, scopolamine, and related antimuscarinic drugs. In: Goodman, L.S. \& Gilman, A. (eds.) The Pharmacological Basis of Therapeutics. 5th Ed. New York: Macmillan (1975) pp. 514-532.

4. Vincent, W. R., BuckBerG, G. D. \& HofFMAN, J.I.E. Left ventricular subendocardial ischemia in severe valvar and supravalvar aortic stenosis. A common mechanism. Circulation 49 326 (1974).

5. Novak, E., Stubas, S.S., Seckman, C.E. \& HEARRON, M.S. Effects of a single large intravenous dose of methylprednisolone sodium succinate. Clin. Pharmacol. Ther, 11: 711 (1970).

6. Novak, E., Stubis, S.S., Sanborn, E.C. \& Eustice, R.M. The tolerance and safety of intravenously administered benzyl alcohol in methylprednisone sodium succinate formulations in normal human subjects. Toxicol. Appl. Pharmacol. 23: 54 (1972).

7. Vyden, J.K., Nagasawa, K., Forrester, J. Corday, E. \& Swan, H.J.C. The Clinical efficacy of corticosteroid administration in acute myocardial infarction. In: Glenn, T.M. (ed.): Steroids and Shock. Baltimore: University Park Press (1974) pp. 424-437.

8. Lillehei, R.C., Dietzman, R.H., Motsay, G.J., SCHULTZ, L.S., Romero, L.H. \& BECKMAN, C.B. The pharmacologic approach to the treatment of shock. I. Defining traumatic, septic and cardiogenic shock. II. Diagnosis of shock and the plan of treatment. Geriatrics $27(7)$ : 73 and $27(8): 81$ (1972).

9. STuBBS, S.S. \& MORRELL, R.M. Intravenous methylprednisolone sodium succinate: adverse reactions reported in association with immunosuppressive therapy. Transplant. Proc. 5: 1145 (1973).

10. MeYers, E.F. \& TOMELDan, S.A. Glycopyrrolate compared with atropine in prevention of the oculocardiac reflex during eye-muscle surgery. Anesthesiology 51: 350 (1979).

11. McCubiln, T.D., Brown, J.H., Dewar, K.M.S., Jones, C.J. \& SPENCE, A.A. Glycopyrrolate as a premedicant: comparison with atropine. Br. J. Anaesth. 51: 885 (1979).

12. PrICE, H.L. Intravenous anesthetics. In: Goodman, L.S. \& Gilman, A. (eds). The Pharmacological Basis of Therapeutics. 5th ed. New York: Macmillan (1975) pp. 97-101.

13. Atkinson, R.S., Rushman, G.B. \& Lee, J.A. A Synopsis of Anaesthesia. 8th ed. Bristol: John Wright \& Sons Lid. (1977) pp. 263-279.

14. DUNDEE, J.W. \& WYANT, G.M. Intravenous Anaesthesia. Edinburgh: Churchill-Livingstone (1974) pp. 23-63

15. Savarese, J.J., Ali, H.H. \& Antonio, R.P. The clinical pharmacology of metocurine: 
dimethyltubocurarine revisited. Anesthesiology 47277 (1977).

16. Savarese, J.J. The autonomic margins of safety of metocurine and d-tubo-curarine in the cat. Anesthesiology 50: 40 (1979).

17. Dottori, O., Häggendal, E., Linder, E., Nordström, G. \& Seeman, T. The haemodynamic effects of nitrous oxide anaesthesia on systemic and pulmonary circulation in dogs. Acta Anaesthesiol. Scand. 20: 429 (1976).

18. LAPPAS, D.G., BUCKLEY, M.J., LAVER, M.B. DAGgetT, W.M. \& Lowenstein, E. Left ventricular performance and pulmonary circulation following addition of nitrous oxide to morphine during coronary-artery surgery. Anesthesiology 43: 61 (1975).

19. Thornton, J.A., Fleming, J.S., Goldberg, A.D. \& Baird, D. Cardiovascular effects of $50 \%$ nitrous oxide and $50 \%$ oxygen mixture. Anaesthesia 28: 484 (1973).

20. Wyant, G.M., Chang, C.A. \& Merriman, J.E. The effect of anaesthesia upon pulmonary circulation. Anesth. Analg. (Cleve.) 4I: 338 (1962)

21. EISELLE, J.H. \& SMith, N.T. Cardiovascular effects of 40 percent nitrous oxide in man. Anesth. Analg. (Cleve.) 51: 956 (1972).

\section{RÉsumé}

Un enfant âgé d'un an et pesant $6.7 \mathrm{~kg}$ a présenté au cours d'une anesthésie, avant le début de la chirurgie (correction d'un retour veineux pulmonaire anormal partiel), un collapsus cardiovasculaire. Cette complication est survenue après l'addition de protoxyde d'azote à l'oxygène inhalé dans une pièce en $T$. Les effets cardiovasculaires de tous les agents utilisés avant cet accident ainsi que ceux du protoxyde d'azote lui-même sont discutés dans le contexte de ce cas particulier. Les agents en cause étaient l'atropine à la dose de $0.1 \mathrm{mg}$ $\left(0.01 \mathrm{mg} \cdot \mathrm{kg}^{-1}\right)$, le glycopyrrolate à la dose de $0.07 \mathrm{mg}\left(0.01 \mathrm{mg} \cdot \mathrm{kg}^{-1}\right)$, la morphine (dose utiliséc: $0.9 \mathrm{mg}$, soit $0.14 \mathrm{mg} \cdot \mathrm{kg}^{-1}$ ), le succinate sodique de méthylprednisone (dose: $165 \mathrm{mg}$, soit $23.5 \mathrm{mg} \cdot \mathrm{kg}^{-1}$ ), le thiopentone $\left(40 \mathrm{mg}\right.$, i.e. $5.7 \mathrm{mg} \cdot \mathrm{kg}^{-1}$ ) et la methocurine $\left(3.4 \mathrm{mg}\right.$. soit $\left.0.5 \mathrm{mg} \cdot \mathrm{kg}^{-1}\right)$. 